\title{
O hospício de outrora sob o juízo de Lima Barreto
}

\section{The Hospice of other Times under the Judgment of Lima Barreto}

\author{
Cinthia Mara Cecato da Silva* \\ Prefeitura Municipal de Colatina - PMC \\ Wilberth Salgueiro* \\ Universidade Federal do Espírito Santo - Ufes
}

RESUMO: A proposta deste artigo é recuperar aspectos do extinto Hospital Nacional de Alienados, por meio das obras Diário do hospício e O cemitério dos vivos (2010), de Lima Barreto (1881-1922). A análise literária dos enredos possibilitará revelar nuanças sobre a instituição que instigam críticas acerca do seu funcionamento no início do século XX, no trato da loucura. Autoritarismo e abuso de poder são narrados no diário do autor carioca e por meio do protagonista do romance, Vicente Mascarenhas. Alinhadas com as proposições do filósofo Michel Foucault, na emblemática História da loucura na Idade Clássica (1978), e em outros pressupostos teóricos pautados pela pesquisadora Beatriz Resende, pela historiadora Magali Gouveia Engel e pelo psiquiatra Paulo Amarante, dentre outros, pretende-se discutir o texto literário levantando hipóteses que contribuam para resgatar histórias sobre o hospício, que transformam o "louco" não em um doente mental, mas em vítima de um sistema.

PALAVRAS-CHAVE: Lima Barreto. Hospício. Loucura.

ABSTRACT: The proposal of this article is to recover aspects of the extinct National Hospital of Alienated, through the works Diário do hospício and $O$ cemitério dos vivos (2010), by Lima Barreto (1881-1922). The literary analysis of the plots will make it possible to reveal nuances

* Doutora em Letras pela Universidade Federal do Espírito Santo (Ufes).

* Doutor em Letras pela Universidade Federal do Rio de Janeiro (UFRJ). Pesquisador do Conselho Nacional de Desenvolvimento Científico e Tecnológico (CNPq) e da Fundação de Amparo à Pesquisa e Inovação do Espírito Santo (Fapes). 
about the institution that instigate criticism about its functioning in the early twentieth century, in the treatment of madness. Authoritarianism and abuse of power are narrated in the diary of the author from Rio de Janeiro and through the protagonist of the novel, Vicente Mascarenhas. Aligned with the propositions of the philosopher Michel Foucault, in the emblematic History of Madness in the Classical Age (1978), and in other theoretical presuppositions ruled by the researcher Beatriz Resende, by the historian Magali Gouveia Engel and by the psychiatrist Paulo Amarante, among others, we intend to discuss The literary text raising hypotheses that contribute to rescue stories about the hospice, which transform the "madman" not into a mentally ill but into a victim of a system.

KEYWORDS: Lima Barreto. Hospice. Madness.

Digo com franqueza, cem anos que viva eu, nunca poderá apagar-me da minha memória essas humilhações que sofri aqui [no hospício].

Lima Barreto

A imagem do jaleco branco-da-paz vestindo os psiquiatras e enfermeiros do Hospital Nacional de Alienados até poderia simbolizar a esperança dos pacientes que fossem conduzidos à Praia da Saudade. Ou até mesmo a "alva" intenção de transformar o espaço asilar em um ícone de modernidade, em virtude de um novo olhar da psiquiatria sobre o "louco". Tudo isso, antes de Lima Barreto. Após a estada do escritor carioca como um dos internos e a publicação de Diário do hospício (DH) e $O$ cemitério dos vivos (CV), essa cena desmoronou, cedendo espaço ao juízo crítico do autor. Por meio dos textos literários, deflagrou o hospício de maneira antes desconhecida: “[...] é a treva absoluta, é toda ausência de luz" (BARRETO [CV], 2010, p. 212). As metáforas que confrontam a ideia de luz e treva, a princípio, parecem fortes para o romance. Elas, todavia, conseguem dar o tom predominante do que Lima Barreto testemunhou durante as internações a que foi submetido: o do "[...] negro absoluto" (BARRETO [CV], 2010, p. 212). As monocromáticas antíteses também adotadas - trevas/luz, branco/negro - simbolizam a contradição de um lugar de tratamento da doença mental que mais excluiu do que curou. 0 Hospital Nacional de Alienados, após as publicações dessas obras do autor, 
transformou-se em um valioso arquivo para análise sobre a tríade manicômio 1 /loucura/práticas asilares, no Brasil, nos idos iniciais do século XX.

As experiências das internações de Lima Barreto em "hospitais de loucos" colaboraram para que ele sentisse "Um vago desejo de morte [...]" (BARRETO [DH], 2010, p. 96), tamanha era a desesperança em virtude das aberrações deflagradas, enquanto paciente asilar e como conhecedor de teorias ligadas àquele contexto. 0 testemunho das inoperâncias e negligências gerou no autor certo inconformismo, dotando-lhe do desejo de trazer à claridade, via literatura, o que estava soterrado nos escombros da história daquele então hospital psiquiátrico, na capital do Rio de Janeiro: “Tenho coligido informações interessantíssimas para escrever um livro sobre a vida interna dos hospitais de loucos" (BARRETO, 2010, p. 295), admitiu ele a um jornalista do Jornal A Folha, durante entrevista concedida de dentro do hospital. 0 diário e a elaboração do romance sobre o hospício tornaram-se, então, o fruto desse projeto.

Amparadas em suas anotações pessoais e na história do alienado Vicente Mascarenhas é que as experiências do autor foram ficcionalizadas. A cada página do enredo, o hospício é invadido e conduz o leitor aos corredores, aos quartos, ao pátio, à chácara, à biblioteca e a outros espaços daquela edificação arquitetônica de inspiração francesa, repositório do contingente de excluídos silenciados pela tutela do Estado. 0 aspecto clássico e luxuoso do amplo hospital, de vista privilegiada da Baía de Guanabara, confrontava-se com o que Lima Barreto alcunhou de "cemitério dos vivos", em virtude do ambiente e das relações mórbidas que presenciou. De posse de tal material, o veio crítico emergiu, trazendo à cena, ao invés do rotulado autor melancólico, o Limamilitante, corajoso o bastante para mirar suas palavras contra alvos antes

\footnotetext{
1 De acordo com o psiquiatra Paulo Amarante (2010, p. 5), "A expressão manicômio, em substituição a hospital psiquiátrico, tem sido utilizada mais especificamente desde 1987, como uma estratégia do MTSM (Movimento dos Trabalhadores em Saúde Mental) no sentido de reforçar o caráter asilar, segregante, violento, tutelar e médico-jurídico de todas as instituições desta ordem. Conceitualmente, pois, para o MTSM, não há distinção entre hospital psiquiátrico, clínica psiquiátrica, asilo, manicômio ou hospício".
} 
inatingíveis, como se consideravam os doutores brasileiros de outrora. Depois de Lima Barreto, as portas do hospício foram escancaradas. Suas obras literárias, nesse certame, são um convite à intimidade daqueles que receberam o estigma de resíduo social, "[...] como um sujeito sem eira nem beira" (BARRETO [DH], 2010, p. 82).

0 acesso ao enredo permite reconstruir as relações estabelecidas entre o corpo de funcionários do hospício e os pacientes asilares. Adianta-se que, apesar de já extinta a escravidão, o vínculo senhor-vassalo ${ }^{2}$ ainda predominava. Longe dos olhares públicos, o bucolismo do hospício dava conta de reproduzir as injustiças cometidas no passado, em virtude da cor, da raça, da condição econômica e da religião. 0 quadro desenhado pelos livros de Lima Barreto sobre o hospício revela-se chocante, pois é a denúncia do desrespeito aos direitos mais elementares dos humanos pacientes. Autorizado a diagnosticar e a tratar, o psiquiatra alcança o topo da hierarquização na ponta de uma pirâmide, dentro da medicina mental. Vinha desse profissional de saúde o diagnóstico sobre a vida dos que preenchiam o chão da geometria social, a partir do momento em que são conduzidos ao hospital pela polícia, ou pela própria família, tornandose exilados sociais, delegando aos psiquiatras seus destinos. Não se sabe, a partir desse momento, o que sucederá: se sairão dali curados, tratados ou até mesmo vivos. Emana do médico o arbítrio sobre os preceitos da Ciência sobre a doença mental àquela época. Origina-se dessa relação totalmente hierarquizada o título de "mestre da loucura", expressão foucaultiana criada para traduzir o grau de autoridade concedido ao médico psiquiatra nos intramuros do hospício.

\footnotetext{
2 Percebe-se dissolvida na literatura barretiana a nítida percepção de como se davam as divisões de classes sociais no regime republicano, evidenciando os efeitos sociais e psicológicos de subserviência de uma injusta hierarquia social. Adeliana Alves Barros, em " $O$ cemitério dos vivos: a experiência manicomial de Lima Barreto", dá destaque a essa relação de dependência quando atesta que, "Diante de uma cultura que se desenvolveu sob um regime colonial dependente, o escritor nos fala dos comportamentos submissos como um traço marcante de nossa cultura voltada ao estrangeirismo, em que a elite cultural e econômica colocava-se submissa ao estrangeiro, por considerá-lo superior pela raça, cultura e nível civilizatório; o povo, em relação às elites, era visto como subserviente, escravo, rústico, agregado, atrasado, preguiçoso, selvagem, sujo e patológico" (BARROS, 2016, p. 54).
} 
Diário do hospício e $O$ cemitério dos vivos tornam-se as referências para alinhavar, de forma crítica, questões do hospício enquanto espaço físico e, ao mesmo tempo, enquanto estratégia política de deter das ruas cariocas segregados sociais de toda sorte, empecilhos para a imagem higienizada que se pretendia conservar.

O espaço asilar, "geena social"?

[...] condenado ao silêncio e ao isolamento mais estúpidos que se podem imaginar, junto a uma quase imobilidade de preso na solitária. Foram dias atrozes.

Lima Barreto

Vicente Mascarenhas revela, no excerto acima, suas funestas impressões sobre

o hospício que o acolheu, enquanto doente mental. Equipara a instituição a uma "solitária", espécie de quadrado destinado aos malfeitores, cujas presenças tornam-se ameaçadoras à sociedade. Isolado do mundo, tornou-se integrante da população do hospício, em que o indivíduo sente-se sozinho, mesmo na companhia de outros internos. A espécie de exílio compulsório vinha acompanhada da impossibilidade de manifestar-se enquanto sujeito, sendo "condenado ao silêncio". O tratamento e o condicionamento "estúpidos" traduzem as práticas "atrozes" vivenciadas naquele lugar em que o paciente, ao invés de sentir-se assistido, é tratado como um "preso". Seriam essas as estratégias do hospício do início do século XX?

Lima Barreto depõe contra o hospício. Sente-se uma vítima dele. Mais que isso, isolado pela condição intelectual, torna-se representante do processo, objetivando desconstruir a identidade de resíduo social atribuída a ele e a todos seus companheiros de reclusão. Para o autor, o hospício era uma prisão como 
outra qualquer, afinal, as grades e os guardas que cerceavam o espaço tinham como propósito impedir a autonomia do paciente. As imposições ao cárcere e a sujeição às rígidas normas e regulamentos estabelecidos pelo estatuto manicomial submetem o paciente ao mesmo tratamento recebido pelo encarcerado delinquente, notadamente quanto ao aspecto da liberdade. A instituição asilar adota a mesma configuração de um cárcere, já que a sua função mais explícita seria proteger a sociedade e salvaguardar os próprios internos doentes de suas insânias.

Sentindo-se preso às rotinas da instituição, o autor observou e fez anotações onde estabeleceu seus próprios paradigmas sobre a loucura, registrando-os de forma direta na espécie de diário, durante sua segunda internação, no Hospital Nacional de Alienados, em função da condição de dependente do álcool. Publicados, os registros foram batizados de Diário do hospício. Essa obra assemelha-se a um caderno de notas ${ }^{3}$. A estrutura é a mesma de um diário coordenado pelo calendário - e o conteúdo expõe as impressões e divagações de Lima Barreto sobre sua própria condição de interno e, principalmente, sobre o cotidiano do hospital. O resultado da escrita, contudo, ultrapassou a mera intenção de registro, pois o diário tornou-se, de acordo com Alfredo Bosi (2010, p. 11) uma das “[...] raras obras que possam valer como testemunhos diretos e coerentes de um estado de opressão e humilhação". A incursão em suas páginas possibilita ao leitor o acesso à estrutura e ao funcionamento do hospital, sob o ângulo crítico do olhar barretiano, que enxerga a instituição como uma verdadeira “[...] geena social [...]” (BARRETO [DH], 2010, p. 48).

\footnotetext{
${ }^{3}$ Diante de condições adversas, o autor se viu obrigado a registrar suas anotações a lápis, em 79 tiras de papel ora pautado (caso dos primeiros dois capítulos), ora sem linha alguma, rascunhadas tanto na frente como no verso. Mais tarde, passou a escrever em tiras maiores e a caneta. Todas as tiras traduzem a enorme preocupação do escritor em dar alguma ordem ao material: datação, numeração de páginas, títulos. Ainda que de forma precária, os manuscritos revelam um trabalho de revisão e pré-edição, registrado por observações do tipo: "aproveitado", "já falei" ou "vide notas". As tiras descartadas foram riscadas e trazem uma anotação ao lado: "já falei”. Esses manuscritos encontram-se na Seção de Manuscritos da Biblioteca Nacional, Coleção Lima Barreto (BARRETO, 2010, p. 42).
} 
A utilização da palavra "geena"4 para traduzir a impressão barretiana sobre o Hospital Nacional de Alienados torna-se capaz de antecipar as conclusões do autor sobre a experiência manicomial. Encontrada na Bíblia em doze passagens, o local - símbolo religioso da destruição eterna - refere-se ao vale Hinom, localizado fora das muralhas que percorriam Jerusalém, funcionando como um depósito de lixo onde eram lançados cadáveres de pessoas julgadas como indignas. A manutenção exigia o uso da substância enxofre para que o fogo destinado a queimar o "lixo" fosse ininterrupto, por isso ser comparado, inclusive, à imagem do inferno. E ainda: local de suplício, de tortura e de tormento. A analogia entre o hospício e a "Geena de Hinom", nessa hipótese, consegue ilustrar o ambiente desolador que aguardava os que fossem encaminhados à instituição asilar - lugar de doentes mentais e, antes de tudo, depósito de excluídos sociais. Em Diário do hospício, Lima Barreto registra a composição de parte da população do Hospital Nacional de Alienados - "geena social" - que dividia com ele o espaço asilar, enquanto sua segunda internação:

Sem fazer monopólio, os loucos são da proveniência mais diversa, originando-se em geral das camadas mais pobres da nossa gente pobre. São de imigrantes italianos, portugueses e outros mais exóticos, são os negros, roceiros, que teimam em dormir pelos desvãos das janelas sobre uma esteira esmolambada e uma manta sórdida; são copeiros, cocheiros, moços de cavalariça, trabalhadores braçais. No meio disto, muitos com educação, mas que a falta de recursos e proteção atira naquela geena social (BARRETO [DH], 2010, p. 48).

Também em 0 cemitério dos vivos, o escritor dá seu testemunho sobre a sorte de indivíduos que compunham o rol de "loucos" dentro do manicômio. Comparar os dois registros contribui para identificar os pontos de contato que

\footnotetext{
4 "A palavra geena é de origem hebraica transliterada para o grego geena, que se encontra 12 vezes na Bíblia: Mateus 5: 22, 29, 30; 10:28; 18:9; 23:15, 33; Marcos 9:43, 45, 47; Lucas 12:2; Tiago. Geena vem do vocábulo hebraico Ge Hinom ou Gé Ben Hinom - "Vale de Hinom" ou "Vale do filho de Hinom". Nesse vale havia uma elevação denominada Tofete, onde ímpios queimavam seus próprios filhos. Este vale se situava a sudoeste de Jerusalém; neste local, antes da conquista de Canaã pelos filhos de Israel, 'canaanitas' ofereciam sacrifícios humanos ao deus Moloque. Terminados os sacrifícios humanos, este local ficou reservado para depósito do lixo proveniente da cidade de Jerusalém. Juntamente com o lixo vinham cadáveres de mendigos encontrados mortos na rua ou de criminosos e ladrões mortos quando cometiam delito" (NICOLAEVSKY, 2004-).
} 
o autor promove entre o real e o ficcional, revelando serem os registros no diário uma espécie de estratégia para dar cabo à sua intenção de produzir um romance sobre o ambiente asilar. 0 trecho abaixo retrata a fala do protagonista Vicente Mascarenhas, exemplificando, desde já, o tipo de movimento promovido entre as obras que, de certa forma, dialogam:

\begin{abstract}
Os loucos são de proveniências as mais diversas; originam-se, em geral, das camadas mais pobres da nossa gente pobre. São pobres imigrantes italianos, portugueses, espanhóis e outros mais exóticos; são negros roceiros, que levam a sua humildade, teimando em dormir pelos desvãos das janelas sobre uma esteira ensebada e uma manta sórdida; são copeiros, são cocheiros, cozinheiros, operários, trabalhadores braçais e proletários mais finos: tipógrafos, marceneiros, etc. (BARRETO [CV], 2010, p. 205).
\end{abstract}

Ambas as passagens dão visibilidade a toda sorte de excluídos que compunham a população do casarão da popular Praia da Saudade. Maria Clementina Pereira Cunha, em sua obra $O$ espelho do mundo - Juquery, a história de um asilo (1986, p. 112), declara que a “[...] rotina do hospício encarrega-se de torná-los [os internos] crescentemente parecidos, até que não haja qualquer diferença fundamental nos rostos e corpos aniquilados". Toda a população inscrita nos cabeçalhos dos prontuários médicos, nessa vertente, tinha como ponte de interseção o marginal, isto é, os internos tinham em comum o estigma de inadaptado social. A marginalidade os equiparava, deixando-os "parecidos", apagando as marcas de suas identidades; suprimindo, a partir da internação, suas histórias de vida de conquistas e de planejamento do futuro. A rotina a que eram submetidos tornava-se o motor do aniquilamento de suas identidades, sem que houvesse “qualquer diferença fundamental" entre eles, apesar da subjetividade intrínseca a cada ser humano. Considerados estorvos para a modernidade que quis avançar galopantemente sobre as terras cariocas, representavam vozes que deveriam ser silenciadas por destoarem do quadro de progresso pintado em tela, na implantação do regime republicano.

Lima Barreto utilizou no registro do diário o verbo "atirar" - "atira naquela 'geena social'" - para traduzir o modo violento como os desvalidos eram 
introduzidos no Hospital Nacional de Alienados. Atira-se para fora o que é dispensável e desprezível. Atira-se para fora o que incomoda ou é inútil. Atiramse para o hospício os restos sociais, camada que representa um empecilho para a imagem imaculada da nação, livre de "impurezas" que destoem do padrão que buscam conquistar, diga-se, a qualquer preço. Esse era o rito de entrada do paciente no hospício de outrora, na percepção de Lima Barreto. Dessa forma se dava a inserção desses desvalidos na "geena social da Praia da Saudade".

Como lixos humanos, "originando-se em geral das camadas mais pobres da nossa gente pobre”, os internos são lançados de qualquer forma naquela espécie de refugo de inadaptados sociais. Trazendo na bagagem, muitos deles, somente uma "esteira esmolambada" e "uma manta sórdida", simbolizam, com esses adereços, a "humildade" que os destituía tanto de bens materiais, como de alguma dignidade para defender-se do compulsório "sequestro social" praticado pela elite e seus interesses de saneamento. Observa-se também que a doença mental não tinha endereço fixo e não apresentava exclusividade a algum tipo de "monopólio", sendo os loucos de "proveniência mais diversa" "pobres imigrantes italianos, portugueses, espanhóis e outros mais exóticos; são negros roceiros", "copeiros, são cocheiros, cozinheiros, operários, trabalhadores braçais e proletários mais finos: tipógrafos, marceneiros".

Contrária a essa diversidade de origem ou de ocupação, estava a condição econômica que os tornavam semelhantes: a pobreza - conforme observou Beatriz Resende em Lima Barreto e o Rio de Janeiro em fragmentos (1993, p. 180): “[...] no hospício, a única identificação que pode ser estabelecida é com a pobreza". Descritos por Lima Barreto, entretanto, deixaram a condição de uma única massa excluída e ganharam rostos que os identificavam, além do direito de terem registradas suas histórias. Mesmo os que tinham "educação" não tinham garantia de "proteção", uma vez que faltavam "recursos" para quaisquer tipos de aprimoramento que os retirassem da condição de segregado social. Do "imigrante" aos tipos "mais exóticos", a população manicomial simbolizava o desarranjo no projeto arquitetônico e de higienização aplicado 
na então capital federal, por isso deveriam ser "tratados" no hospício, deviam esvaziar as ruas, transmitindo uma imagem de organização. É como se o lixo fosse jogado embaixo do tapete, uma vez que suas demandas sociais não eram sanadas com a internação. Beatriz Resende também analisou os dados sobre a procedência dos internos que compuseram o quadro populacional do hospício. Os resultados estatísticos apurados aproximavam-se muito mais a uma estratégia para "sanear [socialmente] a Capital Federal" do que fazer do hospício um local para aplicar as terapias psiquiátricas. Sintetiza a pesquisadora:

\begin{abstract}
Ao assumir a direção da Assistência a Alienados e a direção do Hospício, Juliano Moreira juntava-se ao trabalho de Oswaldo Cruz que passara a dirigir os serviços de saúde Pública. Caberia a ambos desenvolver os projetos do prefeito Pereira Passos para sanear a Capital Federal, livrando-a dos doentes, dos imundos, dos maltrapilhos e dos bêbados e acabar com os focos de infecção e desordem, empecilhos à modernização e à europeização do Rio de Janeiro (RESENDE, 1993, p. 167-168).
\end{abstract}

As autoridades responsáveis por esse processo de saneamento da coletividade, representadas por Juliano Moreira, que assumiu a "direção da Assistência a Alienados e a direção do Hospício"; Oswaldo Cruz, incumbido de administrar os “serviços de saúde Pública” e, também, pelo então Prefeito Pereira Passos, autor dos “projetos" de modernização da capital, imprimiram ao tratamento do louco muito mais um caráter social do que propriamente clínico. A verdadeira intenção não seria diagnosticar e tratar os casos abarcados pela doença mental, mas enquadrar no espaço asilar quaisquer $\operatorname{tipos}^{5}$ que

\footnotetext{
${ }^{5}$ Marco Antonio Arantes em "Para mim, Paraty. Alcoolismo e loucura em Lima Barreto" faz um estudo diacrônico sobre o perfil da população asilar, relatando como se davam as inserções de todos os tipos de pessoas que representassem uma ameaça à modernização da Capital Federal: "De fato, os hospitais psiquiátricos não estavam destinados apenas a receber os loucos, mas grande quantidade de pessoas muito diferentes umas das outras. Com a ampliação de parentescos em torno da loucura, houve crescimento vertiginoso das internações nos hospícios, principalmente depois da Proclamação da República e da promulgação do Decreto n. $206 \mathrm{~A}$, de $15 / 2 / 1890$, que determinava que todo cidadão que perturbasse a ordem pública, a moral e os costumes seria internado em asilos públicos. Inicialmente, todos os indivíduos que perturbavam a tranquilidade pública eram internados no Asilo de Mendicidade e na Casa da Correção, que abrigava também os chamados loucos criminosos. Com a Proclamação da República, e com o início da construção do Hospício Pedro II, todos esses indivíduos foram recolhidos para o novo hospício. Por essa época, o alcoolismo aparecia como uma das causas mais comuns de
} 
representassem um obstáculo "à modernização e à europeização do Rio de Janeiro". Assim como Lima Barreto utilizou o verbo "atirar" para representar a forma como os internos eram introduzidos no espaço do hospício, Beatriz Resende adotou o termo "livrando-se" para traduzir a intenção em conduzir à clínica psiquiátrica não só os indivíduos que manifestassem algum distúrbio mental, mas também os que fossem inadaptados socialmente, isto é, não conseguissem encaixar-se nas padronizações sociais urbanas, determinadas pela burguesia. Dessa forma, no olhar da pesquisadora, além dos "doentes", tornavam-se também "empecilhos" para a "limpeza" da capital os "imundos", os "maltrapilhos" e os "bêbados" - indivíduos causadores de "desordem", desassistidos pelo governo, talvez, sem vínculos familiares que thes oportunizassem as mínimas condições de sobrevivência. O hospício, nesse quadrante, não era de poucos, era de muitos, era de todos os estorvos sociais que ameaçassem macular a imagem límpida da pátria que tinha como lema positivista o "ordem e progresso".

Sobre essa atitude de exclusão praticada pela elite gerencial que transformou o hospício em uma verdadeira "geena social", muito revelou a literatura crítica e rebelde de Lima Barreto. Acostumado a falar literariamente por crônicas publicadas no meio jornalístico, teve, a princípio, sua voz silenciada com a clausura do hospício, como registra Beatriz Resende (1993, 170): “[...] retirado das ruas para a clausura do hospício, a necessidade da escrita terá que encontrar outra forma de expressão, compatível com o isolamento que the é imposto". Nessa situação, não se intimidou, encontrando outras formas para expressar-se. Perceba-se: fez de sua estada um laboratório, fez de sua pessoa uma personagem. Estava preso e era necessário criar um novo canal de comunicação. Os registros das experiências manicomiais tornaram-se matériaprima para sua criação literária acerca do hospício que o acolheu, local onde se amanhece "[...] lembrando que não sabemos sonhar mais..." (BARRETO

internamento em hospícios. A internação de alcoólatras em hospício colocava o álcool não apenas no círculo das drogas legais, mas também no círculo dos venenos sociais" (ARANTES, 2008, p. 3). 
[DH], 2010, p. 50), tamanha era a atmosfera niilista predominante no espaço manicomial. Os sonhos, no hospício, eram desfeitos paulatinamente, a cada atitude de poder contra os indivíduos ali sequestrados, cedendo espaço ao pesadelo de ser tutelado por uma psiquiatria subserviente ao governo, que se preocupou muito mais com sua imagem do que com a sensatez de suas atitudes.

A diversidade populacional detectada no hospício demonstra que à instituição foi designada outra função, além do tratamento dos "loucos". Segundo Michel Foucault ${ }^{6}$, na obra História clássica da loucura (1978), a loucura passa a partir do século XIX a ser enxergada sob um novo prisma, desestabilizando as estruturas tradicionalistas das raízes históricas, edificadas na época clássica. Ao analisá-la ao longo dos séculos - do Renascimento à Modernidade -, o autor francês traça o caminho que a classifica como doença mental, ligada ao alienismo, amparada por um estatuto de cientificidade, diferente da categorização que recebia anteriormente dentro de uma percepção somente social e religiosa. Ultrapassando o mero registro, Michel Foucault firma uma lúcida visão sobre a loucura e sobre a psiquiatria, cujo objetivo mais contundente era o controle do comportamento do indivíduo dentro de uma instituição. Sobre o insulamento da loucura, discorre o filósofo:

\begin{abstract}
A prática do internamento, no começo do século XIX, coincide com o momento no qual a loucura é percebida menos em relação ao erro do que em relação à conduta regular e normal; no qual ela aparece não mais como julgamento perturbado, mas como perturbação na maneira de agir, de querer, de ter paixões, de tomar decisões e de ser livre (FOUCAULT, 1978, p. 48).
\end{abstract}

A principal estratégia da psiquiatria a partir do século XIX - "a prática do internamento" - pode ser lida como excludente e repressora, pois impedia o sujeito de exercer o poder de decisão, o livre arbítrio, o manifestar-se enquanto indivíduo. Prisioneiro, o alienado tinha suas ações conduzidas pelo saber

\footnotetext{
${ }^{6} \mathrm{~A}$ intenção aqui não será esmiuçar o legado foucaultiano sobre a loucura, debruçando-se sobre as obras publicadas do autor que tratam desta temática, mas construir um breve histórico com a proposta de alinhavar questões, a fim de gerar uma melhor compreensão do objetivo deste artigo.
} 
psiquiátrico que determinou “[...] 'o que fazer', 'como', 'quando e onde’ com a pessoa do louco", conforme analisou o psiquiatra e pesquisador Paulo Amarante, no livro $O$ homem e a serpente: outras histórias para a loucura e a psiquiatria (2010, p. 112). Despossuído de direitos sociais, civis e políticos, esse "louco" passou a ser então um "não-sujeito" de destino miserável, cujo estigma teve origem em sua forma diferente "de agir, de querer, de ter paixões, de tomar decisões e de ser livre". Pode-se supor que a internação do desviante, nesse sentido, não pretendia meios para a cura de uma patologia, mas a imposição de um tratamento moral contra certos comportamentos destoantes do padrão moral estabelecido socialmente, incapacitando-o de exercer sua liberdade enquanto cidadão.

Paulo Amarante conclui, ainda, acerca do que sentenciou Michel Foucault: "Se o alienado não é senhor de si, não é sujeito, não é capaz de exercer sua liberdade, deve ser tutelado, dobrado e administrado [...]". Essa postura de alienação onde mais se excluiu do que se integrou, em que esse pseudo-sujeito foi "dobrado e administrado", causou fissuras na prática médica psiquiátrica, condenando-a após determinado período. Os resultados precários auferidos com os internamentos tornaram-se os visíveis reflexos da inabilidade médica no trato da loucura. Temática do campo da saúde mental de larga complexibilidade, permeada por dilemas e por desafios, a loucura exigiu e ainda exige mais do que reclusões e interrogatórios. Michel Foucault estabeleceu orientações fundamentais que servem como eixo de uma nova visada sobre a loucura e o louco, atribuindo-lhe um lugar que, ao invés de diferenciá-lo enquanto sujeito, seja capaz de igualá-lo enquanto um ser social de direitos.

Franco Basaglia - psiquiatra italiano, estudioso de Michel Foucault e autor de várias obras sobre temáticas ligadas à saúde mental - foi o precursor do movimento da reforma da psiquiatria, iniciado em 1970, na Itália. Ele sugeriu a desmontagem do aparelho psiquiátrico que cristalizou o "louco" e a exclusão social dentro do asilo. Suas reflexões apontam que as práticas tradicionalistas 
da especialidade contribuíam para intensificar o grau de miséria humana vivenciado nos hospitais por onde atuou. $O$ isolamento e uma simples humanização, segundo ele, não seriam suficientes para institucionalizar um modelo de assistência psiquiátrica que solucionasse as questões entre a sociedade e a loucura. A crítica de Franco Basaglia à conduta tradicional médica denunciou a postura repressora resultante do afastamento social do louco. Suas observações levaram-no à conclusão de que "[...] ninguém quer mais o manicômio" (BASAGLIA, 2010, p. 11). A negação da instituição manicomial provém de um histórico negativo da psiquiatria, como pode ser visto em Michel Foucault, sobre a adoção do isolamento compulsório como principal tratamento oferecido aos "loucos". A fragilidade dessa base desmascara o taxativo saber médico para a loucura, que se transforma ainda em um imperativo social que visou muito mais a higienização e ao disciplinamento do espaço coletivo do que a busca pela cura do mal, como já exposto.

A visão contemporânea sobre a psiquiatria iluminada pelos estudos de Michel Foucault e ratificada por Franco Basaglia e por tantos outros que se debruçam sobre o tema possibilita um diálogo muito próximo ao que Lima Barreto sentenciou via literatura: o desmascaramento da legitimidade científica da psiquiatria e a verdadeira função do hospício. Quando Basaglia nascia, na Itália, em 1924, e Foucault, na França, em 1926, Lima Barreto já tinha pronta uma espécie de "delação literária" sobre a realidade do hospício e das práticas psiquiátricas no Brasil, expostas, principalmente, em Diário do hospício e $O$ cemitério dos vivos. 0 veredito acerca das marcas do que viveu poderia resumir-se a esta sentença de Vicente Mascarenhas: "Tristes e dolorosas lembranças...” (BARRETO [CV], 2010, p. 179). O reconhecimento do hospício tal como uma "geena social" possibilita ilustrar a função contrária que o hospício desempenhou, conforme expõe Maria Clementina Pereira Cunha:

A literatura recente sobre a história da psiquiatria e da instituição psiquiátrica tem avançado, em outras direções, hipóteses instigantes: em última análise, esta espécie de uso político sem rebuços do saber psiquiátrico, não faria mais que exasperar uma vocação inscrita em sua própria origem histórica, como um conjunto de saberes e de 
práticas engendrado pela e para a ordem burguesa que se instituía (CUNHA, 1986, p. 15).

O olhar agudo apresentado pela historiadora possibilita avaliar o quão visionário foi Lima Barreto em referência ao "uso político sem rebuços do saber psiquiátrico". Suas obras anteciparam "hipóteses instigantes" sobre o hospício. Como nas páginas de um inquérito, registrou seu testemunho: "No Hospício, eu ressenti esse incômodo por quem já se viu recolhido a qualquer prisão; lá, porém, é pior do que em outra qualquer [...]" (BARRETO [CV], 2010, p. 236). 0 "conjunto de saberes e de práticas engendrado pela e para a ordem burguesa que se instituía" descaracterizou a função primeira da instituição manicomial. 0 tratamento dado ao paciente recluso e testemunhado pelo literato carioca expôs de forma concreta ações desumanas e omissões que comprometeram o sucesso da instituição. Transformando o espaço do hospício numa verdadeira Bastilha brasileira, espécie de fortaleza para conter os desajustados sociais, deixou na memória do autor e de seus companheiros de confinamento grande "incômodo", marcando para sempre a vida de cada um deles. Ao invés de insumos de progresso, a psiquiatria exasperou sua "vocação inscrita em sua própria origem histórica", amparando-se em "saberes" e "práticas" que, ao invés de tratar, agiam para instituir a ordem burguesa, preocupada em manterse no controle do país, consolidando sua tradição de poder.

As aguçadas observações do autor sobre o hospício e suas relações contribuem para ratificar a concepção de Paulo Amarante sobre a prática psiquiátrica (2010, p. 111): “A psiquiatria, pretendendo-se ciência, amparando-se em bases frágeis [...] não consegue estabelecer diálogo com a loucura, senão para constatar a sua absoluta estupidez". 0 adjetivo "estupidez" pode parecer impactante a princípio, mas torna-se uma escolha justa para caracterizar a postura autoritária e superficial adotada pela psiquiatria para o tratamento e para a cura da loucura. Houve uma ausência de discernimento por parte dos médicos psiquiatras ao avaliar cada paciente, pois os diagnósticos eram generalizantes, ao invés de seguir uma linha mais subjetiva de investigação. 
Apesar de uma intenção terapêutica, o tratamento moral $^{7}$ pretendido no isolamento não triunfou, pois havia ausência de dedicação e de esforços permanentes caso a caso, comprometendo a eficácia da intervenção psiquiátrica.

Michel Foucault possibilitou um novo olhar sobre as relações entre a razão e a desrazão a partir de suas obras. Abordando questões que põem em voga a loucura, enxergou a psiquiatria como uma peça de poder no jogo de estratégias de controle e dominação do indivíduo rotulado como "louco". A desconstrução dos méritos dessa especialidade médica revoluciona a compreensão sobre a constituição da subjetividade ocidental, tornando-se uma referência para as ciências humanas e, principalmente, para o campo da saúde mental no século $X X$ e ainda neste século.

O legado foucaultiano encontra eco na voz das personagens literárias criadas por Lima Barreto e em sua própria voz, ambas vindas do manicômio, transformando-se em uma teia de significados que ultrapassa a estrutura asilar. Contextualizadas, essas vozes levam o interlocutor a pensar a loucura à época do autor e, ainda, a perceber, por meio de depoimentos e pistas, como se sentia o louco dentro do hospício. 0 tom dos textos literários em análise é crítico e irônico ao mesmo tempo, denunciando o caráter asilar, segregante, violento e tutelar praticado pelo hospital psiquiátrico entre o final do século XIX e o início do XX. As nuanças absolutamente polêmicas flagradas pelo autor põem em xeque as bases adotadas pelo paradigma psiquiátrico, expondo um despotismo ilimitado e o exercício de uma autoridade exorbitante. 0 acesso às narrativas dá ao leitor um passaporte que permite perceber as relações concretas vivenciadas dentro dos muros de um hospício em correspondência ao que

\footnotetext{
${ }^{7}$ Conforme Paulo Amarante (2010, p. 48), "O primeiro e mais fundamental princípio terapêutico do 'tratamento moral', o princípio do 'isolamento do mundo exterior', é uma construção pineliana que até os dias atuais não está totalmente superada. Se as causas da alienação mental estão presentes no meio social, é o isolamento que permite afastá-las, transportando o indivíduo enfermo para um meio no qual as mesmas não podem mais prejudicá-lo”.
} 
ocorria no mundo exterior a esse espaço, podendo ser entendido como um reflexo. A denúncia das arbitrariedades e das falhas da psiquiatria em Lima Barreto é vigorosa, pois contesta, a cada cena, o arsenal teórico da ciência ligado à saúde mental e patenteado pelos alienistas.

Orquestradas sob a regência de médicos psiquiatras, as estratégias de tratamento e as posturas deflagradas pelo autor possibilitam compor um documento literário sobre a implantação da psiquiatria no Brasil. Os textos narrativos em análise, a propósito, conseguem transportar o interlocutor ao cotidiano asilar, estimulando-o a inquirir sobre os referenciais que subsidiaram as bases do saber médico sobre a loucura, podendo, por ora, levar a concluir que "As experiências de luta contra o manicômio no Brasil, como em outros países do mundo, são um testemunho" (BASAGLIA, 2001, p. 12). Testemunho de Lima Barreto contra a dimensão da loucura enquanto estigma, exclusão e violência, constituindo-se como provas em um processo ético contra as práticas asilares, desvelando o caráter discriminatório, determinista e racista da psiquiatria. A contraposição, "[...] a partir daí, se for bem conduzida, deverá levar à vitória da vontade reta, à submissão, à renúncia da vontade perturbada. Um processo, portanto, de oposição, de luta e de dominação" (FOUCAULT, 1978, p. 48-49). O embate sobre a psiquiatria e o espaço que a acolheu, estimulado pela leitura das obras em análise, enfim, torna-se o desejo implícito de Lima Barreto.

A utilização do Hospital Nacional de Alienados para compor os enredos das obras em voga potencializa ainda mais as críticas do autor. 0 uso inadequado do próprio espaço manicomial ajuda a compor as denúncias sobre as práticas asilares. 0 hospício tornou-se, dessa forma, o chão onde ocorreram os tropeços que frustraram as práticas asilares, provando ser, ao invés de um espaço de recuperação, uma verdadeira "geena social". 


\section{O hospício, tal como um "retângulo botânico"}

Assim se estabelece a função muito curiosa do hospital psiquiátrico do século XIX: lugar de diagnóstico e classificação, retângulo botânico onde as espécies de doenças são divididas em compartimentos cuja disposição lembra uma vasta horta. Mas também espaço fechado para um confronto, lugar de uma disputa, campo institucional onde se trata de vitória e submissão.

Michel Foucault

Michel Foucault torna-se referência ${ }^{8}$ para os estudos da história da saúde mental no século XIX com reflexos diretos no século XX, pois discorre sobre o elo entre o poder e a psiquiatria, configurada como prática de dominação do dito "louco". Essa percepção, vista por ele como uma forma de controle social, exposta na obra História da loucura na Idade Clássica (1978), serve como um dos anteparos teóricos para a compreensão do que Lima Barreto quis esboçar criticamente sobre o hospício, a loucura e as práticas asilares gerando alguns embates: por que Foucault aponta como "muito curiosa" a função do hospital psiquiátrico do século XIX-XX?; por que o hospício, como um "campo institucional" é descrito, ao mesmo tempo, como "hospital psiquiátrico" e um "espaço fechado para confronto"?; ao invés de aliados, médico e paciente seriam os antagonistas de um embate?

o paradoxo tem origem quando o alienista mental depositou, de forma ferrenha, sua crença na Ciência como o mais alto patamar do conhecimento. Apoderou-se dessa crença, utilizando-a para controlar a vida dos internos asilares, muitas vezes, de forma arbitrária e autoritária. Essa convicção sobre

\footnotetext{
8 "Dialogando com diferentes áreas do conhecimento acadêmico e científico, tão diversas como a história, a filosofia, a política, a psicologia, a medicina, a psiquiatria, a psicanálise, a literatura, as ciências humanas em geral e outros campos de conhecimento, Michel Foucault foi um crítico feroz do próprio cientificismo e do academicismo dominantes no pensamento francês" (TORRE; AMARANTE, 2017, p. 42).
} 
o poder do alienista sustentado pela Ciência, contudo, pode ser desconstruída uma vez que cabe mais um questionamento: pode a crença ser científica? Sem discorrer sobre o mérito semântico das palavras - ciência/crença - deduz-se que as bases dessa onipotência científica são frágeis, podendo ser questionadas, se aplicadas somente pela frieza da técnica e do "achismo", por meio de padronizações científicas, sem a análise mais detida do caso de cada paciente. Embora sejam "reconhecidas as regularidades da loucura", a uniformização de tratamento atinge diretamente os resultados pretendidos, como assevera Maria Clementina Pereira Cunha:

\begin{abstract}
Mas, por outro lado, reconhecidas as regularidades da loucura no interior do hospício, é igualmente verdade que cada indivíduo representa um quadro doloroso, pessoal e intrasferível, indissociável de sua história de vida, e cuja redução a estatísticas ou generalizações teóricas deixaria perder a própria riqueza da fonte, tanto quanto a dimensão trágica da loucura, fundamental para a questão abordada (CUNHA, 1986, p. 115).
\end{abstract}

O "outro lado" do hospício - aquele que condiciona todos a uma mesma rotina -, segundo analisa a historiadora, reduz o interno a mais um número dos dados "estatísticos" ou das "generalizações teóricas", apagando a "pessoal e intrasferível", a "indissociável" "história de sua vida". Há, nessa ação, um mascaramento sobre o quanto a "dimensão trágica da loucura" pode agir em cada ser humano conduzido à Praia da Saudade. O modelo seguido pela psiquiatria à época de Lima Barreto despreza a "riqueza da fonte", que daria subsídios para uma maior aproximação e análise das características próprias da doença. Isto é, negligencia-se o material de análise, desprezando o "doloroso quadro" apresentado para aprofundar-se nas questões que fazem emergir o comportamento desviante. A presença do psiquiatra, representante do saber científico, não implicou a certeza do diagnóstico de uma doença, mas a vulnerabilidade dos pareceres. A precária técnica dos tratamentos adotados, por conseguinte, pode ser avaliada como inoperante, não fazendo brotar do "retângulo botânico" novos sujeitos, restabelecidos, de alguma forma, do mal que thes acometeu. Cada "compartimento" representava a classificação dada ao doente de forma um tanto quanto aleatória; já o tratamento dispensado era 
padronizado, sem levar em consideração a heterogeneidade daquela população. Cabia ao alienista "julgar” cada paciente conforme o histórico que precedia quaisquer internações, apoiando-se em suas "próprias verdades" acerca da Ciência.

O interno passa, assim, a ser tutelado de modo incondicional ao poder do alienista e ao perímetro do hospício, tendo invadida sua autonomia, sendo suspenso do poder de reflexão sobre si mesmo, enfim, cerceado pelas práticas asilares. O discurso científico amparado na "verdade" endossada como científica passa ser o álibi do médico para impor a "submissão" do paciente mediante seus métodos, garantindo-lhe a "vitória", como se o hospital psiquiátrico fosse um campo de "disputa”, onde devesse haver vencedores. Essas constatações podem dialogar com as impressões acerca do hospício - digase o Hospital Nacional de Alienados, registradas em Diário do hospício e 0 cemitério dos vivos, de Lima Barreto. Encontram-se disseminadas, tanto no diário como no texto ficcional, críticas à instituição responsável em tratar o doente mental, a princípio. De posse desse enredo, o interlocutor poderá projetar uma visão concreta sobre o papel do hospício - enquanto espaço físico - no acolhimento dos internos em tratamento e de desviantes morais no mesmo espaço.

Assemelham-se aos de Lima Barreto e suas críticas ao funcionamento do Hospital Nacional de Alienados os pareceres de Maria Clementina Pereira Cunha sobre o Juquery. Enquanto o autor pauta o Rio de Janeiro, a historiadora faz uma abordagem histórica que traz impressas as marcas do que foi a loucura e os paradigmas de seu tratamento desde o final do século XIX e até a década de 30 do século XX, na capital paulista. Desconstruindo a imagem do hospício como uma instituição modelar de tratamento para a doença mental, a pesquisadora remove os arquivos empoeirados deixando sobre a mesa episódios que descredenciam as práticas asilares daqueles tempos. Ao comparar as abordagens críticas das obras do autor carioca - Diário do hospício e O cemitério dos Vivos e da pesquisadora - O espelho do mundo - Juquery, a história de um 
asilo, podem-se apurar várias intersecções. Ambos desqualificam as práticas asilares em detrimento ao objetivo proposto: tratar e curar os internos.

Sobre as análises realizadas há uma convergência: trata-se o hospício de um espaço de normatização moral, reflexo da sociedade disciplinada extramuros ${ }^{9}$. A visão panorâmica do que representou o espaço asilar permite enxergar normas e rotinas de funcionamento dentro de um mundo confinado. Na opinião de Maria Clementina Pereira Cunha, “[...] o alienismo constitui a primeira destas tecnologias disciplinadoras nascidas no ambiente urbano e voltadas para sua ‘higienização’ e organização” (CUNHA, 1986, p. 28). A edificação de uma cidade "higienizada" e "organizada" tornou-se a política de um conjunto de instituições que objetivavam a padronização dos indivíduos, dos trabalhadores, das famílias, enfim, de toda população da então capital brasileira. Os esforços eram voltados para imprimir uma imagem vitoriosa da burguesia brasileira, fazendo uma verdadeira faxina social, excluindo os "indivíduos "nocivos"” e “não moralizados” do espaço coletivo, como observa a historiadora:

\begin{abstract}
Ainda que sem um projeto muito claro, o poder de fogo do alienismo do início do século está voltado para as tarefas de constituição e difusão de uma dada moralidade, fundada no padrão da família normalizada, da disciplina para o trabalho, da aceitação dos papéis sociais e das rotinas impostas pela vida urbana. Se é este seu objetivo, suas práticas não encontraram ainda uma direção muito determinada: estão voltadas sobretudo para a busca e a exclusão asilar dos indivíduos 'nocivos' e não moralizados em todos os recantos da sociedade (CUNHA, 1986, p. 135).
\end{abstract}

\footnotetext{
9 Segundo Adeliana Alves Barros (2016, p. 20), "Em sintonia com a realidade do período, a medicina mental atuava em busca de conter as epidemias psíquicas, que, generalizadas e incontroláveis, atingiriam o corpo social e o mundo do trabalho, inviabilizando a ordem e o progresso. Assim, pesados investimentos estatais voltaram-se às campanhas de higienização e de salubridade do meio urbano, buscando conter o perigo imediato representado pela presença dos indivíduos viciados, pobres, sujos e improdutivos. À psiquiatria cabia, a partir de instrumentos eficazes de disciplinamento, estabelecer seus pressupostos e verdades na rotina dos indivíduos, tornando-os aptos ao trabalho e à vida em sociedade pautando-se nos moldes burgueses. Diante desse quadro perverso, o alienismo previa para si e propunha para o Estado duas estratégias. De um lado, esquadrinhar o tecido social para localizar e sequestrar os degenerados, ampliando quantitativamente e qualitativamente a internação, criando 'Casas Verdes' para todas as Itaguaís deste Brasil. De outro lado, tratava-se de defender a sociedade, reforçando formas de controle sobre os sãos, introjetando nestes a ideia de sua própria defesa contra os degenerados e a degeneração, incutir-the princípios de moral e de higiene capazes de torná-los permanentemente aptos à disciplina das grandes cidades".
} 
Sem medir esforços, “o poder de fogo do alienismo", resguardado pela estrutura do hospício, quis dar continuidade ao que ocorria na avenida central do Rio de Janeiro: “difusão de moralidade”, instituição do "padrão da família normatizada", implantação da "disciplina para o trabalho", enfim, a imposição das rotinas da "vida urbana". Nesse contexto de moralização dos "recantos da cidade" para a expansão capitalista, o hospício, mais do que um local designado ao tratamento da doença mental, tornou-se uma extensão do projeto de saneamento.

Para Michel Foucault (1978), os saberes sobre a loucura têm como primazia controlar o discurso por procedimentos de interdição e de exclusão, contrariando as funções oficiais ligadas ao manicômio. O filósofo pontua em História da loucura na Idade Clássica, baseado nas razões de Esquirol, as premissas que justificaram a necessidade do enclausuramento como medida de ordem social contra a desordem dos loucos. Ei-las:

1. garantir a segurança pessoal do louco e de sua família;

2. libertá-los das influências externas;

3. vencer suas resistências pessoais;

4. submetê-los a um regime médico;

5. impor-lhes novos hábitos intelectuais e morais (FOUCAULT, 1978, p. 126).

Essas posturas permitem a articulação de dois grandes problemas sociais para a implantação da República: a garantia de harmonia da ordem social e as exigências que preconizam a eficiência terapêutica da internação. Todas essas prerrogativas enumeradas por Esquirol e destacadas por Foucault tornam-se ilusórias e ineficientes, diante das denúncias de Lima Barreto. Os objetivos da criação de um espaço destinado ao tratamento da loucura transfiguram nas obras como uma frustração, sendo que o hospício, para o autor, funcionou muito mais como um local de apartheid social do que como um espaço destinado a apaziguar os sintomas da loucura, por meio do trato terapêutico do isolamento. A missão quase libertária do alienismo, dessa forma, é alvo de 
críticas contundentes provenientes de um profundo espírito de criticidade que capacitou o literato a colocar sob o juízo de suas convicções toda a rotina do hospício, vislumbrando a inoperância dos métodos para tratar ou curar a loucura por meio da intervenção da medicina psiquiátrica.

O pretexto de "garantir a segurança pessoal do louco e suas famílias", mencionado por Michel Foucault, cai por terra quando se conhece que a verdadeira preocupação política e social de afastamento do segregado da via urbana era inserir uma moldura de higienização. Roberto Vecchi, no artigo "Seja moderno, seja brutal: a loucura como profecia da história em Lima Barreto" (1998, p. 120), ao aproximar o hospício de seus reais objetivos "[...] fica com a impressão de que a instituição total do manicômio não passa de uma extensão dos inúmeros infernos sociais que compõem a tumultuosa realidade da capital da República", alvo de uma modernização instalada à força. Muito mais do que "liberá-las das influências externas", a compulsória reclusão criava uma barreira entre o interno e "o resto do mundo", como observa o autor em Diário do hospício: "[...] os internos evitam conversar com os doentes: morgue ou regulamento? No tempo de meu pai não era assim, e desde que eles descobrissem um doente em nossa casa, se aproximavam e conversavam" (BARRETO [DH], 2010, p. 47). Esse parecer de Lima Barreto expõe a falta de humanização e o isolamento destinado aos internos. Denuncia, ao mesmo tempo, a solidão em que se vivia naquele "retângulo", onde se "evitam" quaisquer diálogos que possam servir de refrigério para o isolamento imposto, sem acesso aos ares urbanos que contornavam a instituição, localizada às margens das praias cariocas. 0 autor estabelece, ainda, uma comparação ao que vivenciou no passado, enquanto filho de João Henriques de Lima Barreto, administrador da antiga Colônia agrícola de alienados, localizada na ltha do Governador, também na capital federal. Segundo seu registro, a aproximação entre o interno e seu tutor por meio de "conversa" fazia parte da rotina da instituição, traduzindo-se na relação quase "horizontal" entre eles. Caso o doente precisasse de ajuda, embora não houvesse interferências diretas da ciência psiquiátrica, haveria disponibilidade para tentar entender, mesmo que 
de forma leiga, a causa do problema de forma particular, respeitando a individualidade e a necessidade de cada hóspede temporário da ilha.

O discurso dos alienistas vai sendo, dessa forma, posto em processo depreciativo, revelando, via literatura, a ineficiência na aplicação das práticas asilares. Vicente Mascarenhas, imerso no universo manicomial, consegue arrebatar a impressão que mais the marcava enquanto paciente asilar: "[...] no meu íntimo, eu tinha para mim que tudo aquilo era inútil” (BARRETO [CV], 2010, p. 243). Ao enxergar a rotina do hospício como "inútil", aponta para o descrédito das ações efetivadas dentro do perímetro do hospício. No seu entendimento, todo o aparato que sustentava o funcionamento da instituição era ineficiente, pois não observou quaisquer resultados efetivos nas pretensões para apaziguar as manifestações da doença mental ou dissolver a gênese dos problemas que motivava o comportamento "inadequado" dos desviantes.

Ao invés de "vencer suas resistências pessoais", como asseverou Esquirol, observa-se um efeito contrário, pois, como um dos internos, o autor revela que do hospício não viria a cura para o seu vício ao álcool, mas "Vem então uma melancolia [...] e o pensamento, quando vem para alguma coisa, é para os tristes episódios da nossa vida!" (BARRETO [CV], 2010, p. 243). A marca deixada é de pessimismo contra a instituição e contra si mesmo. O hospício proporcionou, segundo sua impressão, a habitual mania de enxergar-se como incapaz, como um derrotado:

Ouvir durante o dia, senão à noite, disparates e tolices, receber reclamações mais pueris e desarrazoadas, adivinhar manhas perigosas que a insânia engendra, todo esse ambiente moral e intelectual da loucura, tão complicado como a própria vida, [...] uma razão para a tristeza, para renunciamento de si [...] (BARRETO [CV], 2010, p. 233).

A visão de Vicente Mascarenhas sobre o espaço do hospício de forma tão negativa impõe-lhe o "renunciamento de si", fazendo enxergar-se, diuturnamente, como um dos que manifestavam "disparates e tolices" ou dos que proferiam "reclamações mais pueris e desarrazoadas", mesmo sem sê-lo. 
Como poderia o viúvo protagonista superar suas fraquezas humanas em um ambiente onde só havia "razão para a tristeza"? Quais perspectivas teria o desacreditado escritor em enxergar-se de outra forma, recusando o álcool como paliativo de suas frustrações? O entorno muito mais deprimia do que servia como lugar terapêutico para amenização de sua condição instável enquanto "indivíduo-padrão". 0 ambiente asilar apresentava-se, não como um local de apaziguamento das tormentas, mas um espaço "tão complicado como a própria vida". O hospício, cunhado por ele como o "ambiente moral e intelectual da loucura", ao invés de proporcionar certo equilíbrio proveniente das estratégias de tratamento, efetiva-se como um espaço de "manhas perigosas", cercado de "insânia engendrada". Ao invés de proteção, o alienado sentia-se ameaçado, ou por algum companheiro de hospício, ou por si mesmo, sonhando "[...] com a ventura da Morte, que é o sossego" (BARRETO [CV], 2010, p. 223).

Segundo Marco Antonio Arantes, em "Para mim, Paraty - Alcoolismo e loucura em Lima Barreto" (2008, p. 50), o próprio escritor, entre tantos tipos de companheiros de internação, se vê na condição de um objeto nas mãos dos doutores; sendo todos utilizados como "[...] depositários de uma terminologia técnica incompreensível, compulsoriamente desprovidos de direitos civis numa instituição que se mostra autoritária e arbitrária”. Isto é, configuravam-se como um "depósito" de testes que acabava os destituindo dos "direitos civis" dentro da "instituição" manicomial que demonstra, com essa estratégia, ser injusta e "incompreensível". Visto mais como tentativa de experimentação das novas teorias de tratamento para a loucura do paciente que necessitava de acompanhamento psicológico sistematizado, esse interno perde, mais uma vez, o direito de decisão sobre si mesmo, afinal, não tem a opção de escolher se gostaria ou não de ser objeto da pesquisa que visava testar os novos procedimentos no trato da loucura.

Arrogância, autossuficiência, arbitrariedade e imposição de autoridade caracterizam o verdadeiro ambiente do Hospital Nacional de Alienados, local em que Lima Barreto testemunhou a onipotência médica e, ao mesmo tempo, 
a impotência do internado, que já sofrera, durante a vida, outros arbítrios em contrapartida a preconceitos como a cor e a desclassificação social. No olhar do crítico Alfredo Bosi, Lima Barreto e seus companheiros de "casa-forte" tornavam-se verdadeiras "[...] cobaia[s] de alienistas enrijecidos ou precipitados" (BOSI, 2010, p. 34). Também a historiadora Magali Gouveia Engel optou pelo termo "cobaia" para tentar definir a verdadeira função do paciente asilar, em virtude da sua condição de objeto para experimentação científica no hospício, palco para a aplicação das inovações psiquiátricas pretendidas.

\footnotetext{
Criado oficialmente pelas primeiras reformas republicanas com o intuito de promover a interação entre as reflexões teóricas produzidas no ambiente acadêmico e a prática asilar, o Pavilhão de Observação era destinado exclusivamente aos indigentes, transformados em verdadeiras cobaias humanas (ENGEL, 2001, p. 273)
}

Referindo-se a uma ala do hospício denominada "Pavilhão da Observação", em virtude do que era desenvolvido neste espaço, espécie de triagem dos indigentes, local onde se observavam os comportamentos - ou julgava-se pela aparência, Magali Gouveia Engel considera que o uso humano como laboratório, onde seriam experimentadas "a interação entre as reflexões teóricas produzidas no ambiente acadêmico" e a "prática asilar", os transformava em "verdadeiras cobaias humanas". O termo cobaia seria uma escolha justa para identificar os indigentes, aqueles sem quaisquer tipos de vínculos, utilizados como objeto de pesquisa científica. A conotação, entretanto, soa como pejorativa, em vista de trazer a imagem de roedores, funcionando como uma espécie de objeto de teste para descobertas em experimentação. 0 uso do termo "cobaia" retoma também a imagem de ratos nos laboratórios, passando por exames - diga-se, testes - a fim de apurar os possíveis efeitos colaterais provenientes dos estímulos ou substâncias recebidas. Assim como os indigentes do hospício, os animais irracionais - os indigentes-cobaias, não teriam o direito de optar, de ter a livre escolha na participação de algum tipo de pesquisa. Sem vínculos, sem raízes, muitas vezes, sem família, os ratos, assim como os indigentes, não fariam falta. 
Vicente Mascarenhas vê como retrocesso a prática de imposições dentro do hospício. Para o protagonista, os doutores arrogam-se "[...] do direito de crítica, de exame, de livre-exame; e é como se voltássemos ao regímen da autoridade" (BARRETO [CV], 2010, p. 165). Tutelados, submetidos "a um regime médico", assim como propôs Esquirol, o alienado atua como objeto de controle e coerção, sendo mais uma vítima das práticas que buscavam, a priori, homogeneizar a população manicomial. Manipulados, os pacientes têm mais perdas do que ganhos. A perda da identidade, a perda da capacidade de rebelar-se contra a violência do sequestro, a perda de voz para denunciar as arbitrariedades advindas da reclusão imposta...

A quinta premissa destacada por Michel Foucault determina que o hospício deva aos internos "impor-lhes novos hábitos intelectuais e morais". A noção de "novo" aqui deve ser analisada de forma contundente, levantando-se os seguintes questionamentos: quais práticas seriam "novas" no hospício? Quais estratégias de tratamento inovadoras transformariam o ambiente asilar em um local que o desvinculasse do aspecto de prisão?

Joel Rufino do Santos, na obra Épuras do social - Como podem os intelectuais trabalhar para os pobres, cita Lima Barreto como intelectual, estando, contudo, "[...] longe de ser um teórico" (SANTOS, 2004, p. 105) que somente, de longe, discutia as teorias sobre a Ciência da saúde mental e a atuação dos psiquiatras A experiência in loco do literato carioca oportunizou uma rara aproximação entre o autor e o objeto, entre o intelectual e o paciente. Emergiu de sua própria internação, isto é, da própria experiência do lado de dentro das grades do hospício, os pareces sobre a experiência da internação/detenção em um hospício/cárcere. Apesar do estigma de louco que carregou consigo, em virtude de suas alucinações alcoólicas, "A identidade de dor [contudo] não suprimiu a alteridade do intelecto” (p. 105). O Lima-paciente asilar não deixou de ser o Lima-intelectual, aquele crítico costumeiro das práticas de ingerência, cujas consequências eram mais sentidas pelos moradores do subúrbio, seus compatriotas urbanos. A assertiva de que " $O$ intelectual serve para representar 
o pobre" (p. 105) foi o lema adotado por Lima Barreto, se analisadas as suas dezessete obras produzidas, durante uma trajetória de escritor concentrada em dezessete anos. A fala que emerge não provém de teorias engessadas, mas do diálogo entre ele e o outro paciente, seu colega de quarto, talvez. Assumindo a identidade de porta-voz dos sobreviventes asilares, náufragos do sistema que os tornaram "não-sujeitos", o intelectual literário construiu a análise do hospício sendo uma das vítimas do processo que se preocupava em "impor-lhes novos hábitos intelectuais e morais", conforme uma das funções do hospício, destacadas por Michel Foucault.

As imposições determinadas à população asilar atingiram, dessa forma, diretamente o autor que desempenhou todas as ações solicitadas para cumprir a rotina manicomial. Esse lugar, tão próximo ao momento dos fatos, potencializou o importante papel desempenhado pela literatura barretiana, na denúncia de dominação social protagonizada pelos doutores. A experiência, enquanto interno, dotou-lhe de um olhar ainda mais crítico, detector das inoperâncias responsáveis pelos prejuízos causados a cada indivíduo do hospício. Longe de representar um ambiente salutar para o tratamento da loucura, o hospício, na versão barretiana, tornou-se um meio terapêutico de efeito contrário: ao invés de mecanismos de cura, adotava-se o isolamento e a exclusão social. 0 alienismo supõe a ciência determinista como sua arma, transformando os diagnósticos em uma metáfora do poder. Toda a arbitrariedade praticada contra a figura do dito "louco" envolvia médicos, enfermeiros e guardas, sendo influenciada diretamente pelas autoridades policiais. Tanto a cadeia como o asilo compartilhavam, nesse sentido, da mesma função normativa e disciplinar junto àqueles que eram vistos como excedentes ociosos na urbe. Joel Rufino dos Santos assinala que desde "jovem" o autor estaria cônscio de que a elite sempre trabalhava a seu próprio favor:

Compreendeu ainda jovem que os intelectuais pedantes são os funcionários de dissuasão e convencimento (visando ao consenso) da ordem dominante, trabalhando pela humilhação sistemática dos pobres. Viu cedo que o prestígio intelectual, mesmo legítimo, está a serviço da dominação social (SANTOS, 2004, p. 105). 
A "divisão em compartimentos" do hospício - visto como um "retângulo botânico" - equivale às "seções e pavilhões" citados por Lima Barreto em suas obras, cujo espaço é o hospício. Local este, conforme menciona Joel Rufino dos Santos, de "intelectuais pedantes", tentando, a todo tempo, convencer sobre a soberania do doutorismo e, consequentemente, da "ordem dominante" - digase, os desejos da elite. E ainda, trabalhando, como de costume, "pela humilhação sistemática dos pobres", impondo-lhes um lugar de onde não poderiam se erguer. Responsáveis em classificar cada ser humano em uma categoria, dotado de determinada característica unificadora depreciativa, as alas representavam, na totalidade, uma espécie de retaliação social. Acreditava-se que com a tentativa de separação das "espécies", de acordo com as características similares, haveria uma maior facilidade para o tratamento.

A imagem de uma "estufa botânica", "a serviço da dominação social", pode tentar, entretanto, traduzir melhor que um "retângulo botânico" as consequências das divisões por tipos que ocorriam no hospício. Sufocados pelas determinações de seus tutores, os alienados estavam totalmente impedidos de respirar o ar da liberdade, imprescindível para uma terapia que buscasse recuperar a convivência em sociedade e certo equilíbrio psíquico. 0 "prestígio intelectual" não impediu que a imagem de incompetência triunfasse na "casaforte", onde loucos e segregados sociais de todas as vertentes continuaram loucos e segregados sociais. Introduzidos ao espaço do hospício, recebiam de antemão o passaporte para ser subordinado à "ordem dominante", responsável por atribuir-lhes uma nova identidade, em que o adjetivo "louco" corresponderia ao antônimo do adjetivo "livre".

\section{Referências:}

AMARANTE, Paulo Duarte de Carvalho. O homem e a serpente: outras histórias para a loucura e a psiquiatria. Rio de Janeiro: Fiocruz, 1996. 
ARANTES, Marco Antonio. Para mim, Paraty - Alcoolismo e loucura em Lima Barreto. SMAD: Revista Eletrônica de Saúde Mental Álcool e Drogas, Ribeirão Preto, v. 4, n. 1, fev. 2008. Disponível em: <http://pepsic.bvsalud.org/ scielo.php?scrrttext\&pid=S1806-69762008000010>. Acesso em: 7 jun. 2017.

BARRETO, Lima. Diário do hospício. O cemitério dos vivos. Organização de Augusto Massi e Murilo Marcondes de Moura. São Paulo: Cosac Naify, 2010.

BARROS, Adeliana Alves. O cemitério dos vivos: a experiência manicomial de Lima Barreto. 2016. 170f. Dissertação (Mestrado em História) - Programa de Pós-graduação em História, Universidade Federal do Ceará, Fortaleza, 2016.

BASAGLIA, Franco. A instituição negada. 3. ed. Rio de Janeiro: Graal, 2001.

BOSI, Alfredo. Prefácio. In: BARRETO, Lima. Diário do hospício. O cemitério dos vivos. Organização de Augusto Massi e Murilo Marcondes de Moura. São Paulo: Cosac Naify, 2010.

CUNHA, Maria Clementina Pereira. O espelho do mundo: Juquery, a história de um asilo. Rio de Janeiro: Paz e Terra, 1986.

ENGEL, Magali Gouveia. Os delírios da razão: médicos, loucos e hospícios (Rio de Janeiro, 1830-1930). Rio de Janeiro: Fiocruz, 2001.

FOUCAULT, Michel. História da loucura na Idade Clássica. Tradução de José Teixeira Coelho Netto. São Paulo: Perspectiva, 1978.

NICOLAEVSKY, Miguel. Geena. O Vale de Himom. In: ___ (Dir.). Cafétorah. 2004-. Disponível em: <http://www.cafetorah.com/o-vale-de-hinom/ >. Acesso em: 31 maio 2017.

RESENDE, Beatriz. Lima Barreto e o Rio de Janeiro em fragmentos. Rio de Janeiro: UFRJ, 1993.

SANTOS, Joel Rufino dos. Épuras do social: como podem os intelectuais trabalhar para os pobres. São Paulo: Global, 2004.

TORRE, E.; AMARANTE, P. Michel Foucault e a "História da Loucura": 50 anos transformando a história da Psiquiatria. Michel Foucault and the "History of Madness": 50 years Changing the History of Psychiatry. Cadernos Brasileiros de Saúde Mental/Brazilian Journal of Mental Health, n. 3, mar. 2012. Disponível em: <http://incubadora.periodicos.ufsc.br/index.hp/article/view//1725>. Acesso em: 5 abr. 2017.

Recebido em: 12 de junho de 2017. Aprovado em: 28 de novembro de 2017. 